\title{
Sorption of urea hydrogen peroxide by co-pyrolysed bone meal and cow dung slowed-down phosphorus and nitrogen releases but boosted agronomic efficiency
}

\author{
Deogratius Luyima ${ }^{1 \dagger}$, Jwakyung Sung ${ }^{2 \dagger}$, Jae-Han Lee ${ }^{1}$, Seong-Ah Woo ${ }^{1}$, Seong-Jin Park ${ }^{3^{*}}$ and Taek-Keun Oh ${ }^{1^{*}}$ (D)
}

\begin{abstract}
Co-pyrolysis of animal manure biomass with bone meal $(\mathrm{BM})$ and soaking of the resultant biochar in urea containing solutions may offer a sustainable and cheap way of formulating slow-release nitrogen $(\mathrm{N})$ and phosphorus (P) fertilisers. This method can lead to optimisation of the carbon sequestration capacity of the biochar, abatement of environmental pollution by $P$ and $N$ and alleviation of the severity of the projected future scarcity of $P$. A few studies have indicated that sorption can create efficient slow-release fertilisers although all of them utilised charged moieties such as ammonium ions to formulate them and as a result, there is a paucity of data concerning the efficiency of fertilisers formulated using uncharged compounds like urea. It's against that background that we examined the possibility of leveraging co-pyrolysis and sorption with urea containing solutions to formulate slow-release $\mathrm{N}$ and $\mathrm{P}$ fertilisers along with assessing the agronomic efficiency of the formulated fertilisers through cultivating lettuce in pots for two seasons. Both urea-hydrogen peroxide (UHP) and urea were utilised as N sources. UHP (CDBM-UHP) and urea (CDBM-Urea) containing biochars averagely released $64.40 \%$ and $87.00 \%$ of the added $\mathrm{N}$, respectively over the 28 -day incubation period with the amount of $\mathrm{N}$ released decreasing with increasing concentrations of $\mathrm{BM}$ in the biochar. Lettuce yields and nutrient use efficiencies of $\mathrm{N}$ and $\mathrm{P}$ were higher in the CDBM-UHP than in the CDBM-Urea treatments. It's therefore clear that sorption of UHP by BM containing biochar concomitantly slows-down releases of $\mathrm{N}$ and $\mathrm{P}$ and boosts the agronomic efficiency of the fertilisers.
\end{abstract}

Keywords: Agronomic efficiency, Biochar, Real nutrient use efficiency, Slow-release fertilisers, Sorption

\section{Introduction}

Nitrogen $(\mathrm{N})$ and phosphorus $(\mathrm{P})$ are irreplaceable nutrient elements in the sustenance of agricultural production systems and life in general [1]. Their usage for supporting plant growth has been growing since the green revolution

\footnotetext{
*Correspondence: archha98@korea.kr; ok5382@cnu.ac.kr

${ }^{\dagger}$ Deogratius Luyima and Jwakyung Sung equally contributed to the present study as co-first authors

1 Department of Bio-Environmental Chemistry, College of Agriculture and Life Sciences, Chungnam National University, Daejeon 34134, Korea ${ }^{3}$ Division of Soil and Fertilizer, National Institute of Agricultural Science, RDA, Wanju 55365, Korea

Full list of author information is available at the end of the article
}

in the second half of the twentieth century and are highly credited for boosting agricultural productivity and reducing global hunger. However, continuous fertilisation of agricultural fields has resulted in plenty of problems including the exacerbated release of greenhouse gases, particulate matter precursors, underground and surface water pollution, etc., mainly arising from moderately low nutrient uptake by crops $[1,2]$. These losses don't bode well for the future supply of $\mathrm{P}$ in particular because although $\mathrm{N}$ supply is unlimited due to the Haber Bosch process which produces about $100 \mathrm{Tg}$ of $\mathrm{N}$ per year [3], phosphate rock reserves are finite and thus should be optimally utilised $[3,4]$. 
Besides the injurious ramifications on environmental quality and human health, the speedy release of $\mathrm{P}$ into the soil exacerbates its fixation especially in acidic and highly weathered soils [5]. Of particular importance to this conundrum are animal manures with abnormally high $\mathrm{N}$ : $\mathrm{P}$ ratios which hamper their sustainable recycling. Whereas the $\mathrm{N}$ to $\mathrm{P}$ ratios of most plant biomass average to around 8:1, those of animal manure do not exceed 4:1, thus, the application of livestock manure at optimal $\mathrm{N}$ crop requirements portends $\mathrm{P}$ accumulation in the soil [6] - with possible contamination of groundwater through leaching or eutrophication of open water sources through surface runoff $[7,8]$. Although animal manure has historically been a valuable resource in amending soils and providing crop nutrients, the increasingly large scale animal operations confined to small geographic areas have resulted in the generation of enormous quantities of manure far beyond the assimilative potentials of the lands nearby $[6,9]$. Therefore, disposal of manure has increasingly become a problem, prompting farmers to stockpile it under uncontrolled conditions something that hastens its decay resultantly magnifying the emissions of ammonia and other harmful gases like methane and nitrous oxide [10,11].

Pyrolysis, if leveraged can sustainably solve the abovementioned problems both through shrinking the volumes of the generated animal wastes and more importantly by providing cheap carrier and coating materials for plant nutrient elements in form of biochar, hydrochar and biooil which have great capacities to lessen nutrient releases into the environment. The potentialities and or efficacies of different products of pyrolysis in slowing-down releases of plant nutrients especially nitrogen have been widely assessed by several studies which include amongst others Chen et al. [12], Punga et al. [13], Ye et al. [14] and Liu et al. [15]. The results from all those studies confirm that products of pyrolysis are efficient in slowing down the release of easily leachable plant nutrient elements with resultant benefits for environmental quality and agricultural productivity. To slow the release of $\mathrm{P}$ from animal manure biochar, studies by Zhao et al. [16] and Lustosa Filho et al. [5] mulled the idea of co-pyrolysing biomass with $\mathrm{P}$ sources and found that co-pyrolysing animal manure biomass with $\mathrm{P}$ did not only slow down $P$ release but also improved carbon retentions in the resultant biochar. With diminishing phosphate rock (PR) reserves, it's vital to assess the performance of alternative (renewable) sources of P like bone waste.

Formulating slow-release $\mathrm{N}$ and $\mathrm{P}$ fertilisers from copyrolysed bone waste and animal manure can offer a sustainable way of controlling discharges of $\mathrm{N}$ and $\mathrm{P}$ into the environment from both animal excrement and mineral fertilisers. While several strategies of synthesising biochar based slow-release $\mathrm{N}$ fertilisers (BFs) have been proposed by different studies, the easiest and cheapest of all of them is $\mathrm{N}$ fertiliser sorption by biochar. This is because pelletising the formulated fertilisers or wrapping them in superabsorbent polymers increases production costs and can also pose grave environmental problems especially if synthetic polymers are overused. Indeed, previous studies by Yao et al. [17] and Chen et al. [18] found sorption an effective method of producing slowrelease fertilisers even though both employed charged rather than the chemically inactive fertiliser forms. Moreover, An et al. [19] suggested that merging biochar and nutrients through sorption is an inapt undertaking because the amalgamation is mainly controlled by the weak van der Waals forces, thus weakening the slowrelease capacity of the formulated fertilisers. The present study, therefore, aimed to examine the possibility of formulating slow-release $\mathrm{N}$ and $\mathrm{P}$ fertilisers both through co-pyrolysis of animal manure biomass (cow dung) with $\mathrm{BM}$ and soaking of the resultant biochar in urea and UHP solutions alongside assessing the agronomic efficiency of the formulated fertilisers.

\section{Materials and methods \\ Characterisations of BFs and soil}

Rendered bone waste was finely ground into BM, sieved through a $2 \mathrm{~mm}$ strainer and mixed with cow dung in two different ratios of $1: 1$ and 1:3, respectively. The cow dung had also been dried and strained through a $2 \mathrm{~mm}$ sieve. The mixtures were pyrolysed at $500{ }^{\circ} \mathrm{C}$ and then soaked in urea and UHP solutions to form CDBM-Urea and CDBM-UHP, respectively. The urea and UHP containing fertilisers formulated out of the 1:3 amalgams are denoted as CDBM 1-Urea and CDBM 1-UHP, respectively while CDBM 2-Urea and CDBM 2-UHP represent urea and UHP containing fertilisers, respectively, made out of the 1:1 mixture. Additionally, CDTP-Urea and CDTP-UHP fertilisers formulated out of an admixture containing $75 \%$ cow dung and $25 \%$ triple super phosphate (TSP) and pyrolysed at $500{ }^{\circ} \mathrm{C}$ were included for purposes of comparing BM to a conventional source of P. All the formulated fertilisers were oven dried for $24 \mathrm{~h}$ at $105^{\circ} \mathrm{C}$. Both urea and UHP were mixed with co-pyrolysed biochars in ratios of $1: 5$, respectively.

The total carbon $(\mathrm{C})$ and total nitrogen $(\mathrm{TN})$ of the biochar-based slow-release $\mathrm{N}$ fertilisers formulated (BFs) were determined with a $\mathrm{C} / \mathrm{N}$ analyser, total $\mathrm{P}$ in both BFs and soil was extracted by paying strict adherence to the aqua regia method and analysed for orthophosphate following a method espoused by Murphy and Rilley [20] after neutralising the supernatant with $4 \mathrm{M} \mathrm{NaOH}$ using p-nitrophenol indicator. Available $\mathrm{P}$ in BFs was extracted with $2 \%$ formic acid (Formic P) and analysed 
colourimetrically at $470 \mathrm{~nm}$ following the vanadatemolybdate method. Soil extractable P was extracted with Olsen solution, filtered and then assessed for orthophosphate following the ascorbic acid method proposed by Murphy and Rilley [20]. Determination of the total elemental compositions of BFs followed extraction with the perchloric acid (wet ashing) and measurements of the resultant filtrates with ICP-OES. Concentrations of soil mineral elements including $\mathrm{K}, \mathrm{Ca}, \mathrm{Mg}$ and $\mathrm{Na}$ were determined with ICP-OES after extraction with $1 \mathrm{~N}$ neutral ammonium acetate solution. $\mathrm{pH}$ of the BFs was determined in a 1:10 BFs: water suspension. The nutrient compositions and other chemical properties of the BFs are shown in Table 1 below while the properties of the soil used are given in Luyima et al. [32].

\section{Releases of $\mathrm{N}$ and $\mathrm{P}$ from the BFs}

The $\mathrm{N}$ and $\mathrm{P}$ release potentials of the BFs were conducted through a simple batch experiment which was carried out by mixing two grams of each of the BFs with $200 \mathrm{~mL}$ of deionized water and then agitated at $60 \mathrm{rpm}$ on a reciprocating shaker at $25^{\circ} \mathrm{C}$. Two portions of $5 \mathrm{~mL}$ each of the suspension (one for $\mathrm{N}$ and the other for $\mathrm{P}$ analysis) were collected at regular intervals, filtered through $0.45 \mu \mathrm{m}$ Advantec membrane filters and analysed for $\mathrm{N}$ and P. For $P$ release analysis, suspensions were collected at $8,16,24$, $48,72,96,120,144,168,216,264,312,384,456,552$ and $672 \mathrm{~h}$ while for $\mathrm{N}$ analysis, suspensions were collected at $24,48,72,96,120,144,168,216,264,312,384,456,552$ and $672 \mathrm{~h}$ although the cumulative amounts of both $\mathrm{N}$ and $P$ released were graphically presented in days instead of hours. P contents of the filtrated suspensions were analysed following the ascorbic acid method proposed by Murphy and Rilley [20] while the total N concentrations were determined colourimetrically following a method developed by Okalebo et al. [21]. P sources evaluated included CDBM 1, CDBM 2, TSP and BC. Values of
CDBM 1 and CBM 2 were obtained by averaging P concentrations of both urea and UHP containing CDBM 1 and CDBM 2, respectively. Each of the Changes in N and $\mathrm{P}$ concentrations as a function of time were fitted using nutrient release kinetic models including zero order, first order, pseudo first, second order, pseudo second, Elovich, power function, and parabolic diffusion models as were documented by Sparks [22] and Zhao et al. [16].

\section{Evaluation of the agronomic efficiency of BFs}

To assess the agronomic efficiency of the different BFs, two seasons of pot experiments were conducted with the leaf lettuce. BFs amendments were CDTPUrea, CDTP-UHP, CDBM 1-Urea, CDBM 1-UHP, CDBM 2-Urea, CDBM 2-UHP while control and treatments where P sources of BC and TSP, each separately added to the pots applied with urea and UHP were also included. Each of the BFs was applied to the soil at a rate of $0.5 \%(\mathrm{w} / \mathrm{w})$ which translates to 15 metric tons of BFs per hectare (considering a soil with a bulk density of $1.5 \mathrm{~g} / \mathrm{cm}^{3}$ and an incorporation depth of $20 \mathrm{~cm}$ ) and each growing season lasted for 5 weeks after transplanting of two-week-old seedlings. Regular watering and other agronomic practices were carried out to ensure proper growth and development of the planted lettuce. At each harvest, agronomic characteristics of the leaf lettuce including shoot weight, shoot height, root weight, root length, number of leaves, leaf length and leaf width were determined. Additionally, plant uptakes of $\mathrm{N}$ and $\mathrm{P}$ under the different soil amendments were also assessed to delineate the $\mathrm{N}$ and $\mathrm{P}$ use efficiencies. Plant sample analysis followed strict adherence to the analytical methods espoused by Kalra [23]. Total nitrogen was determined through the miro-Kjeldahl method while total $\mathrm{P}$ was assessed by paying adherence to the nitric-perchloric acid digestion in an open vessel method. The real nitrogen (RNUE) and phosphorus

Table 1 Selected properties of the BFs, TSP and BC

\begin{tabular}{|c|c|c|c|c|c|c|c|c|c|}
\hline \multirow[t]{2}{*}{ Treatment } & \multirow[t]{2}{*}{$\mathrm{pH}$} & \multicolumn{2}{|c|}{ Elemental content (\%) } & \multirow[t]{2}{*}{$\mathrm{C} / \mathrm{N}$ ratio } & \multirow{2}{*}{$\begin{array}{l}\text { Total P } \\
\left(\mathrm{mg} \mathrm{g}^{-1}\right)\end{array}$} & \multirow[t]{2}{*}{ Formic $\mathbf{P}$} & \multirow[t]{2}{*}{$\mathrm{K}$} & \multirow[t]{2}{*}{$\mathrm{Ca}$} & \multirow[t]{2}{*}{ Mg } \\
\hline & & C & $\mathbf{N}$ & & & & & & \\
\hline BC & $9.98 \pm 0.0$ & $14.33 \pm 2.6$ & $2.71 \pm 0.5$ & $5.29 \pm 0.5$ & $150.9 \pm 1.4$ & $23.06 \pm 4.5$ & $3.25 \pm 0.2$ & $313.11 \pm 8.4$ & $5.88 \pm 0.3$ \\
\hline TSP & $3.44 \pm 0.0$ & $0.21 \pm 0.1$ & $0.04 \pm 0.0$ & $5.25 \pm 0.4$ & $205.6 \pm 4.2$ & $34.93 \pm 1.0$ & $6.37 \pm 0.4$ & $167.08 \pm 5.6$ & $6.63 \pm 0.0$ \\
\hline CDBM 1-Urea & $8.53 \pm 0.1$ & $35.11 \pm 3.1$ & $12.70 \pm 0.1$ & $2.76 \pm 0.1$ & $85.8 \pm 2.9$ & $10.73 \pm 0.3$ & $2.53 \pm 0.3$ & $216.10 \pm 8.1$ & $4.89 \pm 0.2$ \\
\hline CDBM 1-UHP & $8.99 \pm 0.0$ & $35.09 \pm 2.8$ & $11.93 \pm 0.1$ & $2.94 \pm 0.0$ & $85.5 \pm 3.5$ & $10.72 \pm 0.5$ & $2.66 \pm 0.1$ & $216.19 \pm 7.7$ & $5.00 \pm 0.5$ \\
\hline CDBM 2-Urea & $8.86 \pm 0.1$ & $27.01 \pm 2.7$ & $13.12 \pm 0.2$ & $2.06 \pm 0.0$ & $127.8 \pm 1.8$ & $16.52 \pm 2.9$ & $3.03 \pm 0.5$ & $270.81 \pm 7.5$ & $5.41 \pm 0.1$ \\
\hline CDBM 2-UHP & $9.02 \pm 0.1$ & $27.04 \pm 2.5$ & $12.90 \pm 0.1$ & $2.10 \pm 0.1$ & $128.0 \pm 1.7$ & $16.60 \pm 3.2$ & $2.98 \pm 0.3$ & $270.85 \pm 7.9$ & $5.16 \pm 0.1$ \\
\hline CDTP-Urea & $6.05 \pm 0.1$ & $37.21 \pm 1.9$ & $11.67 \pm 0.8$ & $3.19 \pm 0.5$ & $122.7 \pm 2.0$ & $18.64 \pm 1.1$ & $4.20 \pm 0.2$ & $180.04 \pm 7.3$ & $6.17 \pm 0.5$ \\
\hline CDTP-UHP & $6.17 \pm 0.1$ & $37.16 \pm 2.2$ & $11.44 \pm 0.1$ & $3.25 \pm 0.2$ & $123.0 \pm 2.3$ & $18.65 \pm 0.8$ & $4.18 \pm 0.2$ & $180.90 \pm 6.8$ & $6.12 \pm 0.0 .7$ \\
\hline
\end{tabular}

$B C$ bone char, TSP triple superphosphate, CDBM $175 \%$ cow dung $+25 \%$ bone meal (3:1 mixture), CDBM $250 \%$ cow dung $+50 \%$ bone meal (1:1 mixture), CDTP $75 \%$ cow dung $+25 \%$ bone meal. 
(RPUE) use efficiencies of the applied fertilisers were computed from the equation espoused by Wang and Zhou [24] as follows; of cumulative $\mathrm{N}$ obtained at equilibrium (qe) reduced with increasing proportions of BM in the co-pyrolysed biochar and was higher in the CDBM-Urea than in the

$$
\begin{aligned}
& \text { RNUE }=\frac{\mathrm{N} \text { uptake by plants in the fertilised plot }-\mathrm{N} \text { uptake by plants in the control }}{\text { Fertiliser N }- \text { Residual N }} * 100 \\
& \text { RPUE }=\frac{\text { Puptakebyplantsinthefertilisedplot }- \text { Puptakebyplantsinthecontrol }}{\text { TotalPapplied }- \text { RemnantPattheendofthegrowingseason }} * 100
\end{aligned}
$$

For each treatment in the first season except the control, two sets were set up one of which was used for computations of the nutrient use efficiencies in the first growing season while the other was utilised as the control experiment in the second growing season. Therefore, each of the treatments had its control experiment in the second growing season.

\section{Statistical analysis}

The data from the pot experiments were subjected to a single factor analysis of variance (ANOVA) using the Microsoft Excel 16 version and the results obtained were subjected to a tukey post hoc test with the $\mathrm{p}$ value set at $5 \%$ using the studentised $q$ tables. The statistical differences amongst different treatments were denoted by small letters of the English alphabet while the standard deviation on graphs were indicated with error bars.

\section{Results}

\section{$\mathrm{N}$ and $\mathrm{P}$ releases from the $\mathrm{BFs}$}

As shown in Fig. 1, CDBM-Urea fertilisers released more $\mathrm{N}$ than their CDBM-UHP counterparts. For example, CDTP-Urea cumulatively released $964.52 \mathrm{mg} / \mathrm{g}$ of $\mathrm{N}$ during the 28-day period of the experiment whereas CDTP-UHP liberated $715.35 \mathrm{mg} / \mathrm{g}$ of the soaked N. In the same vein, BFs formulated from cow dung co-pyrolysed with $B M$ released far less $N$ than those made out of cow dung co-pyrolysed with TSP. The amount of N released from the BM containing BFs diminished with increasing BM concentrations in the BFs. For example, CDBM 1-Urea cumulatively freed $841.30 \mathrm{mg} / \mathrm{g}$ of $\mathrm{N}$ vis-a-vis $804.00 \mathrm{mg} / \mathrm{g} \mathrm{N}$ obtained from CDBM 2-Urea. Relatedly, the amount of $\mathrm{N}$ cumulatively released from CDBM 1-UHP in the 28 days of the experiment stood at $629.42 \mathrm{mg} / \mathrm{g}$ while CDBM 2-UHP cumulatively discharged $586.46 \mathrm{mg} / \mathrm{g}$.

Apart from CDTP-Urea whose $\mathrm{N}$ release best fitted to both the pseudo first and pseudo second orders $\left(\mathrm{R}^{2}=0.995\right), \mathrm{N}$ release from the remainder of the BFs was best fitted to only the pseudo second order of kinetic release as indicated in Table 2. The quantity
CDBM-UHP fertilisers. For example, the obtained qe stood at $997.33 \mathrm{mg} / \mathrm{g}$ in the CDTP-Urea but reduced to 914.29 and $866.67 \mathrm{mg} / \mathrm{g}$ in CDBM 1 -Urea and CDBM 2-Urea, respectively. The lowest qe value of $644.83 \mathrm{mg} / \mathrm{g}$ was obtained with CDBM 2-UHP. Similar to $\mathrm{N}$ release, $\mathrm{P}$ release from all the BFs fitted well to the pseudo second order of release kinetics.

$\mathrm{BC}$ released $1.58 \mathrm{mg} / \mathrm{g}$ of $\mathrm{P}$ over the entire period of the experiment while CDBM 1 and CDBM 2 released lower quantities of 0.42 and $0.79 \mathrm{mg} / \mathrm{g}$ P, respectively. On the other hand, TSP cumulatively discharged $299.10 \mathrm{mg} / \mathrm{g}$ while CDTP liberated $125.74 \mathrm{mg} / \mathrm{g}$ of $\mathrm{P}$ as shown in Fig. 2. TSP and $\mathrm{BC}$ discharged 77.63 and $82.84 \%$, respectively of the total $\mathrm{P}$ cumulatively released over the entire experimental period with in

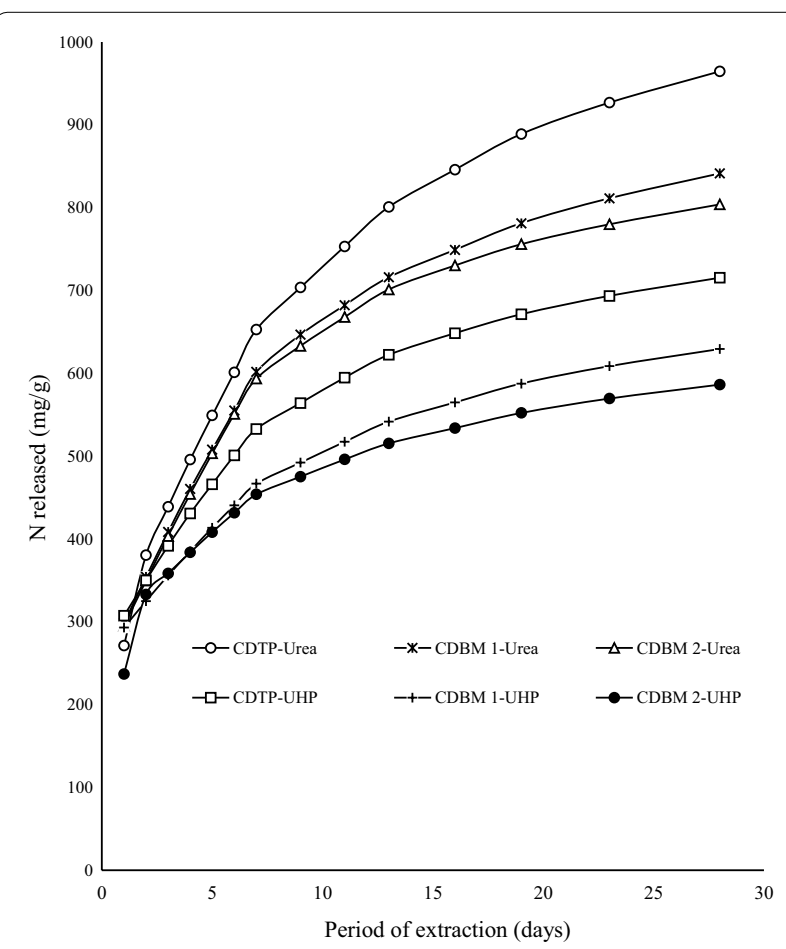

Fig. 1 Cumulative $\mathrm{N}$ released over a 28-day incubation period by different BFs 
Table 2 Coefficients $\left(R^{2}\right)$ of the examined models and the rate constants for $\mathbf{N}$ and $\mathrm{P}$ release kinetics from co-pyrolysed biochar based fertilisers

\begin{tabular}{|c|c|c|c|c|c|c|c|c|c|c|c|}
\hline \multirow[t]{2}{*}{ Kinetic models } & \multicolumn{3}{|c|}{$\mathrm{N}$ in Urea form } & \multicolumn{3}{|c|}{$\mathrm{N}$ in UHP form } & \multicolumn{5}{|c|}{ Phosphorus } \\
\hline & CDTP & CDBM 1 & CDBM 2 & CDTP & CDBM 1 & CDBM 2 & TSP & CDTP & BC & CDBM 1 & CDBM 2 \\
\hline \multicolumn{12}{|c|}{ Zero order $[A]_{t}=[A]_{0}-k_{0} t$} \\
\hline $\mathbf{R}^{2}$ & 0.239 & 0.195 & 0.218 & 0.168 & 0.138 & 0.209 & 0.283 & 0.386 & 0.197 & 0.816 & 0.894 \\
\hline $\mathrm{k}_{0}$ & -3.5733 & -3.6761 & -3.8937 & -3.6511 & -3.1932 & -3.2819 & -0.0785 & -0.0142 & -0.0004 & $-2 \times 10^{-5}$ & $-7 \times 10^{-5}$ \\
\hline \multicolumn{12}{|c|}{ First order $\log [A]_{t}=\log [A]_{0}-\frac{k_{1}}{2.303} * t$} \\
\hline $\mathbf{R}^{2}$ & 0.417 & 0.417 & 0.523 & 0.382 & 0.252 & 0.356 & 0.493 & 0.622 & 0.387 & 0.876 & 0.939 \\
\hline $\mathrm{k}_{1}$ & -0.0398 & -0.0449 & -0.0544 & -0.0488 & -0.0401 & -0.0539 & -0.0039 & -0.0016 & -0.0037 & -0.0009 & -0.0018 \\
\hline \multicolumn{12}{|c|}{ Pseudo first order $\ln \left(q_{e}-q_{t}\right)=\ln q_{e}-k_{1 b} * t$} \\
\hline $\mathbf{R}^{2}$ & 0.995 & 0.987 & 0.981 & 0.976 & 0.998 & 0.971 & 0.924 & 0.984 & 0.930 & 0.979 & 0.956 \\
\hline$k_{1 b}$ & -0.1079 & -0.0787 & -0.0825 & -0.0659 & -0.0952 & -0.0675 & -0.0050 & -0.0035 & -0.0052 & -0.0029 & -0.003 \\
\hline \multicolumn{12}{|c|}{ Second order $\frac{1}{[A]_{t}}=\frac{1}{[A]_{0}}+k_{2} t$} \\
\hline $\mathbf{R}^{2}$ & 0.659 & 0.737 & 0.873 & 0.755 & 0.528 & 0.587 & 0.866 & 0.841 & 0.707 & 0.926 & 0.918 \\
\hline $\mathrm{k}_{2}$ & 0.0006 & 0.0008 & 0.0012 & 0.0012 & 0.0010 & 0.0015 & 0.0005 & 0.0002 & 0.0941 & 0.0375 & 1.1084 \\
\hline \multicolumn{12}{|c|}{ Pseudo second order $\frac{t}{q_{t}}=\frac{1}{k_{2 b} * q_{e}^{2}}+\frac{1}{q_{e}} * t$} \\
\hline $\mathbf{R}^{2}$ & 0.995 & 0.996 & 0.997 & 0.996 & 0.995 & 0.998 & 1.000 & 0.992 & 1.000 & 0.991 & 0.993 \\
\hline$q_{e}$ & 997.33 & 914.29 & 866.67 & 800.00 & 654.78 & 644.83 & 303.03 & 135.86 & 1.59 & 0.48 & 0.92 \\
\hline$k_{2 b}$ & 0.00025 & 0.00030 & 0.00035 & 0.00041 & 0.00057 & 0.00062 & 0.00019 & 0.00010 & 0.05472 & 0.0165 & 0.0099 \\
\hline \multicolumn{12}{|c|}{ Elovich $q_{t}=\frac{1}{\beta} \ln (\alpha \beta)+\frac{1}{\beta} \ln t$} \\
\hline $\mathbf{R}^{2}$ & 0.990 & 0.984 & 0.984 & 0.985 & 0.979 & 0.980 & 0.840 & 0.983 & 0.762 & 0.971 & 0.819 \\
\hline \multicolumn{12}{|c|}{ Power function $\ln q_{t}=\ln k+v \ln t$} \\
\hline $\mathbf{R}^{2}$ & 0.988 & 0.985 & 0.980 & 0.989 & 0.991 & 0.957 & 0.710 & 0.976 & 0.654 & 0.969 & 0.966 \\
\hline \multicolumn{12}{|c|}{ Parabolic diffusion $q_{t}=A+C * t^{1 / 2}$} \\
\hline $\mathbf{R}^{2}$ & 0.968 & 0.959 & 0.946 & 0.961 & 0.975 & 0.972 & 0.629 & 0.957 & 0.559 & 0.972 & 0.956 \\
\hline
\end{tabular}

$\mathbf{R}^{2}$ values (in bold) are an important indication of the strength of the fit to the different kinetic models by the tested BFs fertilisers

$[\boldsymbol{A}]_{t}$ is the concentration of $\mathrm{N}$ or $\mathrm{P}$ at time $\mathrm{t},[\boldsymbol{A}]_{0}$ is the initial concentration of $\mathrm{N}$ or $\mathrm{P}, \boldsymbol{q}_{\boldsymbol{t}}$ is the cumulative concentration of $\mathrm{N}$ or $\mathrm{P}$ at time $\mathrm{t}, \boldsymbol{q}_{\boldsymbol{e}}$ is the cumulative quantity of $\mathrm{N}$ or $\mathrm{P}$ obtained at equilibrium of the experiment, $[A]_{t}=\boldsymbol{q}_{t 2}-\boldsymbol{q}_{\mathbf{t} 1}$ where $\boldsymbol{q}_{\mathbf{t} 2}$ is the cumulative concentration of $\mathrm{N}$ or $\mathrm{P}$ at the current sampling and $\boldsymbol{q}_{\boldsymbol{t} 1}$ is the cumulative concentration of $\mathrm{N}$ or $\mathrm{P}$ at the preceding sampling

$B C$ bone char, TSP triple superphosphate, CDBM $175 \%$ cow dung $+25 \%$ bone meal (3:1 mixture), CDBM $250 \%$ cow dung + 50\% bone meal (1:1 mixture), CDTP $75 \%$ cow dung $+25 \%$ bone meal.

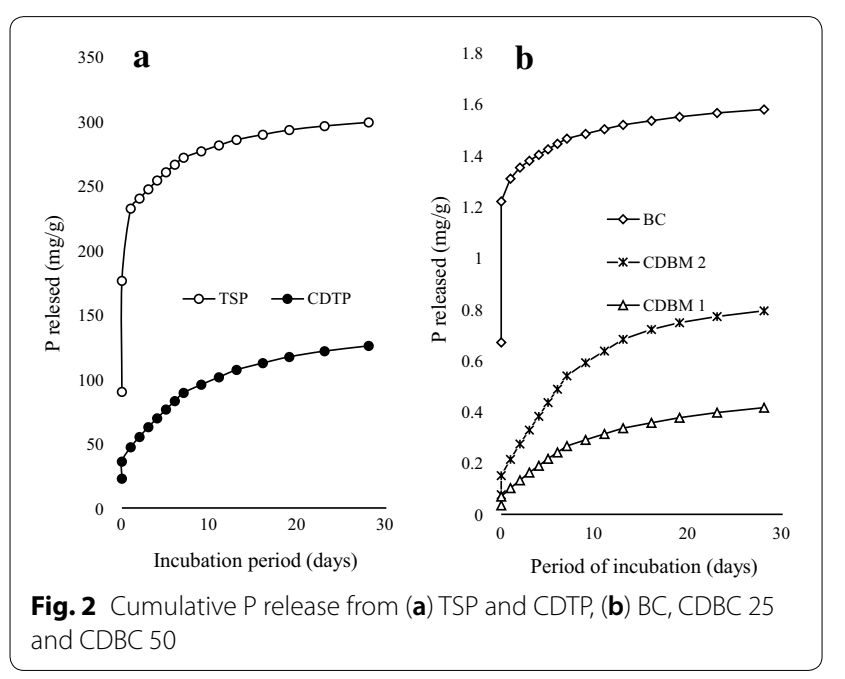

the first $24 \mathrm{~h}$. Additionally, the qe values of 303.03 and $1.59 \mathrm{mg} / \mathrm{g}$ obtained for TSP and BC, respectively were higher than the values obtained with the co-pyrolysed biochars of CDBM 1, CDBM 2 and CDTP whose qe totalled to only $0.48,0.92$ and $135.86 \mathrm{mg} / \mathrm{g}$, respectively as shown in Table 2.

\section{Agronomic efficiency of BFs}

Apart from the control and treatments where TSP and urea or UHP were separately added to the soil (which either registered losses or no change in yields), the rest of the treatments experienced boosted yields in the second season of the experiment as shown in Table 3. CDTPUHP produced the most stellar performance in almost all the aspects of crop yields assessed in both the growing seasons and was closely followed by CDTP-Urea amendment. In the second season, the differences in yield between the ordinary urea treatment of TSP + Urea 
Table 3 Yield components

\begin{tabular}{|c|c|c|c|c|c|c|c|c|}
\hline $\begin{array}{l}\text { Growing } \\
\text { seasons }\end{array}$ & Treatments & $\begin{array}{l}\text { Shoot weight } \\
\text { (g/pot) }\end{array}$ & $\begin{array}{l}\text { Shoot length } \\
(\mathrm{cm})\end{array}$ & $\begin{array}{l}\text { No. of leaves } \\
\text { (per plant) }\end{array}$ & $\begin{array}{l}\text { Leaf width } \\
\text { (cm) }\end{array}$ & $\begin{array}{l}\text { Leaf length } \\
\text { (cm) }\end{array}$ & Root weight (g) & $\begin{array}{l}\text { Root length } \\
(\mathrm{cm})\end{array}$ \\
\hline & CDTP-Urea & $78.45 \pm 5.34 \mathbf{f}$ & $22.30 \pm 1.04 \mathbf{e}$ & $16.00 \pm 1.00 c$ & $6.90 \pm 0.17 \mathbf{f}$ & $15.67 \pm 1.15 \mathbf{d}$ & $15.97 \pm 0.06 \mathbf{e}$ & $19.00 \pm 0.46 \mathbf{e}$ \\
\hline & CDTP-UHP & $82.53 \pm 3.88 \mathbf{g}$ & $23.60 \pm 0.44 \mathbf{f}$ & $15.00 \pm 1.73 b \mathbf{b c}$ & $7.73 \pm 0.51 \mathbf{g}$ & $16.33 \pm 0.58 \mathbf{d}$ & $16.53 \pm 0.46 f$ & $20.50 \pm 0.82 f$ \\
\hline & $\begin{array}{l}\text { CDBM } \\
\text { 1-Urea }\end{array}$ & $71.87 \pm 1.63$ de & $19.13 \pm 1.2 \mathrm{cbc}$ & $15.33 \pm 0.58 \mathbf{b c}$ & $5.90 \pm 0.62 \mathbf{e}$ & $14.50 \pm 0.50 \mathbf{c}$ & $14.03 \pm 0.03 \mathbf{d}$ & $17.10 \pm 0.75 \mathbf{d}$ \\
\hline \multirow[t]{10}{*}{ Season 1} & CDBM 1-UHP & $74.20 \pm 2.11 \mathbf{e}$ & $20.50 \pm 0.50 \mathbf{d}$ & $15.00 \pm 1.00 \mathbf{b c}$ & $5.33 \pm 0.58 c$ & $14.80 \pm 0.20 c$ & $14.10 \pm 0.30 \mathbf{d}$ & $17.70 \pm 0.36 \mathbf{d}$ \\
\hline & $\begin{array}{l}\text { CDBM } \\
\text { 2-Urea }\end{array}$ & $67.63 \pm 1.52 \mathrm{~cd}$ & $17.80 \pm 0.95 \mathrm{cbc}$ & $13.00 \pm 0.00 \mathbf{b}$ & $5.63 \pm 0.15$ de & $13.33 \pm 0.42 \mathbf{b}$ & $12.89 \pm 0.25 \mathbf{b c}$ & $15.70 \pm 0.53 c$ \\
\hline & CDBM 2-UHP & $71.00 \pm 2.00 \mathbf{d}$ & $18.20 \pm 0.36 \mathbf{b c}$ & $14.00 \pm 1.00 \mathbf{b}$ & $5.10 \pm 0.10 c$ & $13.00 \pm 0.30 \mathbf{b}$ & $13.07 \pm 0.11 c$ & $15.90 \pm 0.10 c$ \\
\hline & TSP + Urea & $58.00 \pm 0.98 \mathbf{b}$ & $17.00 \pm 0.20 \mathbf{b}$ & $19.00 \pm 2.00 \mathbf{d}$ & $4.33 \pm 0.15 \mathbf{b}$ & $16.00 \pm 0.36 \mathbf{d}$ & $12.44 \pm 0.50 \mathbf{b}$ & $13.50 \pm 0.50 \mathbf{b}$ \\
\hline & $\mathrm{TSP}+\mathrm{UHP}$ & $62.33 \pm 2.42 \mathbf{c}$ & $17.40 \pm 0.70 \mathbf{b}$ & $16.00 \pm 2.65 c$ & $4.95 \pm 0.06 c$ & $15.60 \pm 0.20 \mathbf{c d}$ & $12.63 \pm 0.21 \mathbf{b c}$ & $13.40 \pm 0.44 \mathbf{b}$ \\
\hline & $\mathrm{BC}+$ Urea & $63.60 \pm 0.69 c$ & $17.9 \pm 0.53 \mathrm{cbc}$ & $14.67 \pm 0.50 \mathbf{b c}$ & $4.37 \pm 0.12 \mathbf{b}$ & $14.37 \pm 0.47 c$ & $13.22 \pm 0.33 c$ & $13.7 \pm 0.35 \mathbf{b}$ \\
\hline & $\mathrm{BC}+\mathrm{UHP}$ & $64.81 \pm 1.60 c$ & $18.6 \pm 0.79 c$ & $15.33 \pm 0.35 \mathbf{b c}$ & $5.50 \pm 0.25 \mathbf{d}$ & $14.83 \pm 0.55 c$ & $13.46 \pm 0.48 c$ & $13.67 \pm 0.65 \mathbf{b}$ \\
\hline & Control & $37.16 \pm 1.25 \mathbf{a}$ & $9.50 \pm 0.62 \mathbf{a}$ & $6.00 \pm 1.00 \mathbf{a}$ & $3.67 \pm 0.35 \mathbf{a}$ & $5.67 \pm 0.25 \mathbf{a}$ & $3.99 \pm 0.46 \mathbf{a}$ & $5.30 \pm 0.72 \mathbf{a}$ \\
\hline & CDTP-Urea & $102.20 \pm 1.75 f$ & $26.53 \pm 1.34 \mathbf{d}$ & $21.67 \pm 1.53 \mathbf{d}$ & $8.17 \pm 0.21 \mathbf{d}$ & $14.93 \pm 0.90 \mathrm{de}$ & $26.26 \pm 0.73 \mathbf{d c d}$ & $20.00 \pm 1.73 \mathbf{c d}$ \\
\hline & CDTP-UHP & $123.30 \pm 2.34 \mathbf{h}$ & $27.90 \pm 1.01 \mathbf{e}$ & $28.00 \pm 1.00 f$ & $9.57 \pm 0.51 \mathbf{e}$ & $15.70 \pm 0.36 \mathbf{e}$ & $29.50 \pm 1.32 \mathbf{e}$ & $20.53 \pm 1.36 \mathbf{d}$ \\
\hline \multirow[t]{9}{*}{ Season 2} & $\begin{array}{l}\text { CDBM } \\
\text { 1-Urea }\end{array}$ & $99.37 \pm 1.12$ ef & $25.23 \pm 0.93 \mathbf{c d}$ & $18.67 \pm 0.58 c$ & $7.33 \pm 0.64 \mathbf{c d}$ & $14.67 \pm 0.58 \mathbf{d}$ & $24.18 \pm 2.37 \mathbf{c d}$ & $20.30 \pm 0.36 \mathbf{c d}$ \\
\hline & CDBM 1-UHP & $109.98 \pm 3.77 \mathbf{g}$ & $26.00 \pm 1.00 \mathbf{d}$ & $25.33 \pm 1.53 \mathbf{e}$ & $8.90 \pm 0.85 \mathbf{e}$ & $15.43 \pm 0.51 \mathbf{e}$ & $24.45 \pm 1.08 \mathbf{c d}$ & $20.07 \pm 0.67 \mathbf{c d}$ \\
\hline & $\begin{array}{l}\text { CDBM } \\
\text { 2-Urea }\end{array}$ & $96.71 \pm 2.06 \mathbf{e}$ & $24.50 \pm 0.72 c$ & $19.00 \pm 1.73 c$ & $7.30 \pm 0.53 \mathbf{c d}$ & $14.37 \pm 1.00 \mathbf{d}$ & $23.08 \pm 1.76 c$ & $19.10 \pm 0.85 c$ \\
\hline & CDBM 2-UHP & $100.84 \pm 2.26$ ef & $26.40 \pm 0.60 \mathbf{d}$ & $19.33 \pm 0.58 c$ & $7.77 \pm 0.25 \mathbf{d}$ & $15.60 \pm 0.87 \mathbf{e}$ & $23.21 \pm 0.82 \mathbf{c}$ & $19.57 \pm 1.26 \mathbf{c d}$ \\
\hline & TSP + Urea & $51.36 \pm 3.24 \mathbf{b}$ & $21.97 \pm 0.95 \mathbf{b}$ & $16.67 \pm 0.58 \mathbf{b}$ & $5.93 \pm 0.12 \mathbf{b}$ & $11.23 \pm 0.25 \mathbf{b}$ & $10.71 \pm 0.45 \mathbf{b}$ & $13.00 \pm 0.87 \mathbf{b}$ \\
\hline & $\mathrm{TSP}+\mathrm{UHP}$ & $62.88 \pm 1.97 c$ & $22.70 \pm 0.66 \mathbf{b}$ & $17.00 \pm 1.00 \mathbf{b}$ & $6.37 \pm 0.55 b \mathbf{b}$ & $13.03 \pm 0.35 c$ & $12.05 \pm 0.83 \mathbf{b}$ & $14.63 \pm 0.32 \mathbf{b}$ \\
\hline & $\mathrm{BC}+$ Urea & $89.27 \pm 5.14 \mathbf{d}$ & $23.10 \pm 0.36 \mathbf{b}$ & $19.33 \pm 0.58 c$ & $6.90 \pm 0.36 c$ & $14.13 \pm 0.86 \mathbf{d e}$ & $24.64 \pm 0.62 \mathbf{c d}$ & $19.90 \pm 1.15 \mathbf{c d}$ \\
\hline & $\mathrm{BC}+\mathrm{UHP}$ & $93.33 \pm 2.10 \mathrm{de}$ & $24.87 \pm 0.57 c$ & $21.00 \pm 1.00 \mathbf{d}$ & $7.13 \pm 0.32 \mathbf{c d}$ & $15.00 \pm 0.30 \mathrm{de}$ & $25.08 \pm 1.08 \mathbf{d}$ & $19.73 \pm 1.76 \mathbf{c d}$ \\
\hline & Control & $36.62 \pm 2.02 \mathbf{a}$ & $8.83 \pm 0.29 \mathbf{a}$ & $9.67 \pm 0.58 \mathbf{a}$ & $4.40 \pm 0.17 \mathbf{a}$ & $6.73 \pm 0.46 \mathbf{a}$ & $3.23 \pm 0.18 \mathbf{a}$ & $5.27 \pm 0.47 \mathbf{a}$ \\
\hline
\end{tabular}

The letters ( $\mathbf{a}-\mathbf{h}$ ) denote the significant differences between the different treatments based on the result of the Tukey posthoc test

$B C$ bone char, TSP triple superphosphate, CDBM $175 \%$ cow dung $+25 \%$ bone meal (3:1 mixture), CDBM $250 \%$ cow dung $+50 \%$ bone meal (1:1 mixture), CDTP $75 \%$ cow dung $+25 \%$ bone meal.

and the best performing BF amendment of CDTP-UHP was $71.94 \mathrm{~g}$ implying that the latter outperformed the former by a factor of more than two. Besides economic yield, BFs also produced the longest and heaviest roots of all the treatments. For example, while the TSP + Urea treatment produced $12.44 \mathrm{~g}$ and $13.50 \mathrm{~cm}$ of root weight and root length, respectively, the corresponding BF fertiliser amendment of CDTP-Urea produced $15.97 \mathrm{~g}$ and $19.00 \mathrm{~cm}$ of root weight and root length, respectively which translates to respective 10.32 and 40.74 percentage increments.

Apart from TSP treatment that registered a decreased RPUE in the second season, application of the remainder of the biochar amendments led to increased phosphorus use efficiencies by plants in the second season. In both seasons, the phosphorus use efficiency was higher in the CDTP amendment followed in the decreasing order by CDBM 2, CDBM1, BC and TSP as presented in Fig. 3. In the first growing season, the RPUE by lettuce stood at $59.8 \%$ of the phosphorus applied in the form of CDTP while the use efficiencies of CDBM 2, CDBM 1, BC and TSP stood at $56.73,51.70,45.80$ and $44.00 \%$, respectively. The largest improvement in RPUE in the second season came from CDTP which increased by 6 percentage points to $65.80 \%$. This was followed by BC which registered a $3.9 \%$ percentage point increment to $49.70 \%$ whereas CDBM 2 and CDBM 1 amendments recorded respective percentage point increases of $2.87 \%$ and $2.90 \%$. The RPUEs of TSP and $\mathrm{BC}$ were not significantly different in the first season even though the $\mathrm{BC}$ amendment posted a higher RPUE value.

In terms of nitrogen use efficiency, the lowest RNUE in both seasons came from the TSP + Urea amendment as shown in Fig. 4. The RNUE of TSP + Urea stood at $51.73 \%$ in the first season but decreased by 4.86 percentage points to $46.87 \%$ in the second lettuce growing season. Applying TSP together with UHP instead of urea (TSP + UHP) improved the RNUE to $55.86 \%$ in the first growing season and although it reduced by 1.80 percentage points to $54.06 \%$ in the second season, the value obtained in the second season was 7.19 percentage points 


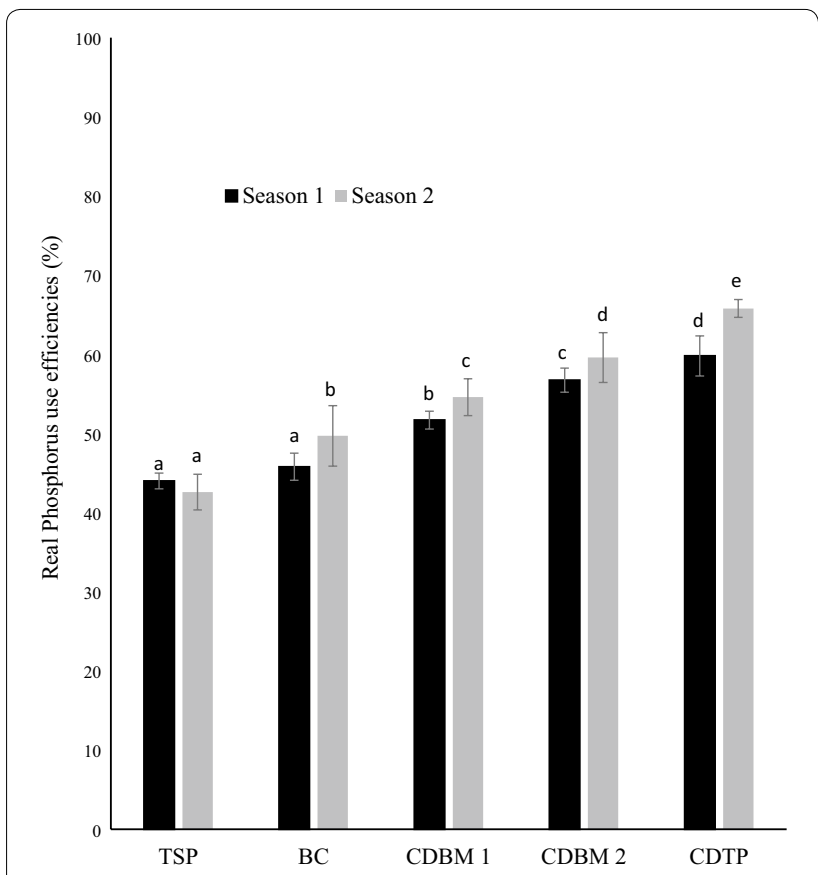

Fig. 3 Real phosphorus use efficiencies (RPUE) of the various $P$ sources higher than that obtained with TSP + Urea. The RNUE achieved with TSP + UHP amendment was not significantly different from that obtained with $\mathrm{BC}+$ Urea in the first season but the latter produced an RNUE better than the former in the second season. Apart from the TSP + Urea and TSP + UHP amendments which elicited decrements in the RNUE in the second season, the remainder of the amendments/treatments produced increases in RNUE in the second season. The increments in RNUE in the second season were generally higher in the BM containing BFs than in their TSP containing counterparts. The largest augmentation came from CDBM 1-Urea with a 7.00 percentage point increase whilst CDBM 2-UHP, CDBM 2-Urea and CDBM 1-UHP produced 6.33, 6.23 and 4.00 percentage point increases, respectively of the RNUE in the second season.

As shown in Fig. 4 above, the UHP containing BFs generally recorded higher RNUE values than their urea containing counterparts. For example, CDTP-UHP amendment effected an RNUE of $64.76 \%$ in the first season against a value of $61.50 \%$ produced with CDTP-Urea and the trend was observed across all other amendments and the two experimental seasons. The highest RNUE values of $77.30 \%$ and $83.63 \%$ in the first and second seasons, respectively were achieved with CDBM 2-UHP

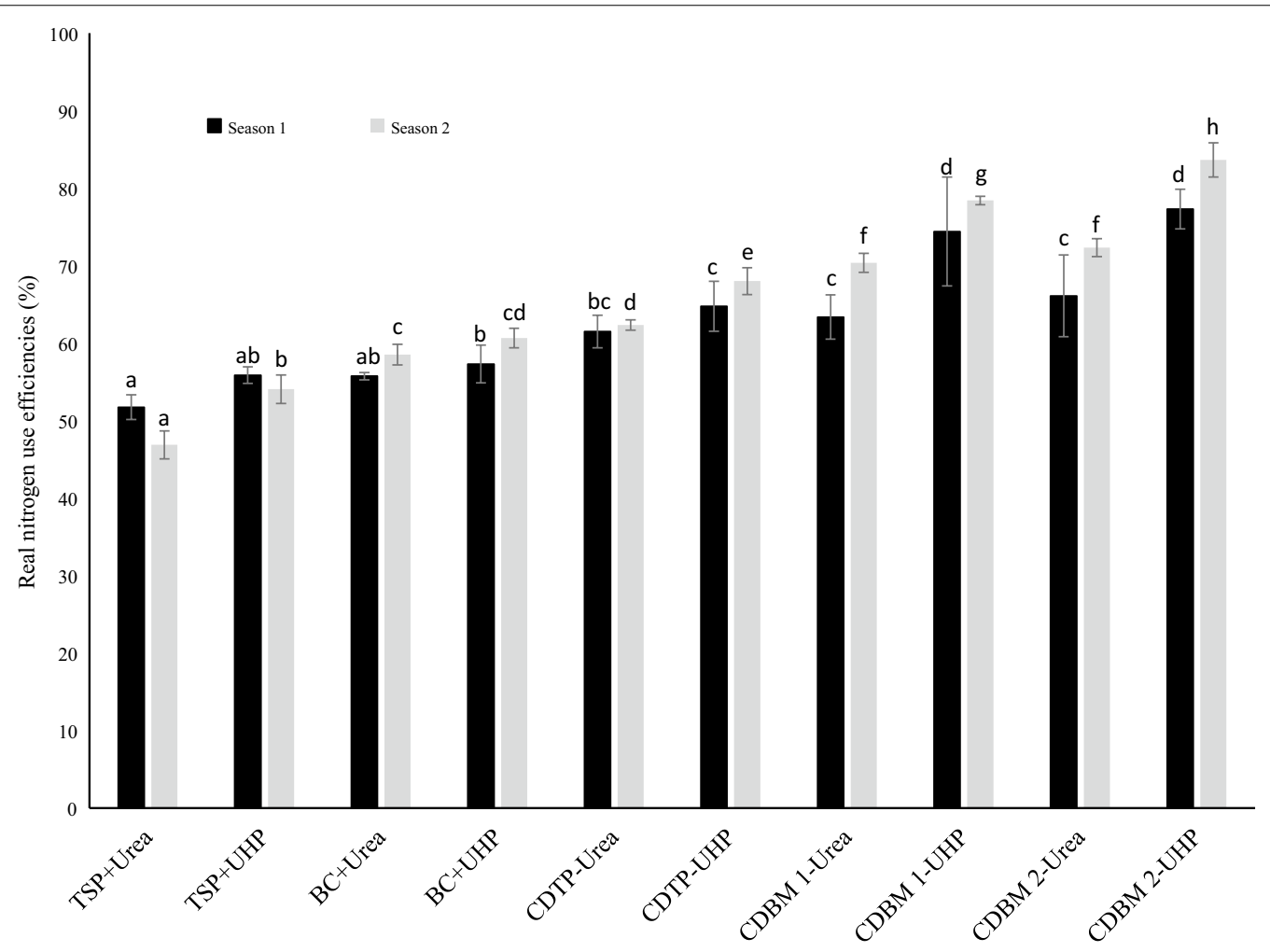

Fig. 4 Real nitrogen use efficiencies (RNUE) of the various BFs 
amendment. This was followed by CDBM 1-UHP which produced RNUE values amounting to 74.40 and $78.40 \%$ in the first and second seasons, respectively. The RNUEs were generally higher in the BM containing BFs than in the TSP containing BFs and the values increased with increasing concentrations of BM in the BFs.

\section{Discussions}

\section{Slow releases of $\mathrm{N}$ and $\mathrm{P}$ from BBFs}

Several former studies have illuminated biochar's high affinity for the different forms of $\mathrm{N}$ which concomitantly reduces their release. A case in point is a study by Cai et al. [25] which revealed that biochar derived from agricultural wastes exhibited high affinity for ammonium ions with the absorptivity increasing with decreasing pyrolysis temperatures. The adsorbed ammonium ions were strongly held by biochar to the extent that the desorbed fractions ranged from less than $10 \%$ to about $30 \%$ of the adsorbed quantities with biochars pyrolysed at higher temperatures desorbing more ammonium ions than those pyrolysed at low temperatures. They attributed their observations to the oxygen functional groups of $\mathrm{COOH}, \mathrm{C}=\mathrm{O}, \mathrm{COC}$ present on the biochar surface which tightly hold ammonium ions through electrostatic interactions and hydrogen bonding.

Biochar's ability to adsorb nitrates has also been well documented by Prost et al. [26], Kammann et al. [27], Ventura et al. [28], Haider et al. [29] and others. In fact, a study by Haider et al. [30] indicated that the adsorbed nitrates are held tightly that the standard extraction methods underestimate them and that extractions must be repeated several times before all the captured nitrates can be released. That aforementioned affinity for the different forms of $\mathrm{N}$ observed in the above mentioned studies may explain the slow release behaviour of the urea soaked in the biochar of the present study because urea dissolution in water produces ammonium ions that might have been adsorbed through the mechanisms mentioned above. A Fourier transform infra-red spectrum of a UHP containing biochar fertiliser taken by Chen et al. [12] revealed existence of more $\mathrm{C}-\mathrm{O}$ moieties than in pure biochar indicating that the hydrogen peroxide carried along with urea in the UHP complex oxidised the carbonised surfaces, thus enhancing the biochar's adsorption ability. This might offer an explanation for the better slow release of $\mathrm{N}$ obtained with CDBM-UHP as compared to the CDBM-Urea fertilisers. This is because charged ions such as ammonium and nitrate, formed at the disintegration of the UHP complex might have been subsequently absorbed by the superb adsorption sites caused by the peroxide.

Even though research into BFs is still in a fledgling state, the few available studies overwhelmingly substantiate the slow release capabilities of the fertilisers with the level of efficiency of the slow release capacities heavily dependent on the preparation methods used. For example, Liu et al. [15] indicated that a fertiliser produced by mixing biochar and urea through grinding slowed $\mathrm{N}$ release by less than $10 \%$ in the first 28 days of the experiment while formulating the same mixture under a sealed reactor led to a slight increase in the slow release capacity of the resultant fertiliser. Additionally, halving the urea concentration while doubling the biochar content and adding bentonite to the mixture in the sealed reactor produced a fertiliser that released only $86.7 \%$ of $\mathrm{N}$ which accentuated an improvement in the slow release potential of the produced fertiliser. The study explicated that the most efficient slow release fertilisers were produced when polyvinyl alcohol was added to urea, bentonite and biochar in the sealed reactor with the amount of $\mathrm{N}$ released decreasing with increasing biochar, bentonite and polyvinyl alcohol concentrations and decreasing urea content in the mixture.

The results of the Liu et al. [15] experiment demonstrate therefore, that mere mixing of biochar with urea has little impact on slowing $\mathrm{N}$ release and that more means of improving urea absorptivity into biochar should be explored if the slow release potentials of the generated fertilisers are to be maximised. Basing on that line of thought, it's surprising that mere soaking of biochar in UHP solutions undertaken in the current study produced more efficient slow release $\mathrm{N}$ fertilisers than the hydrothermal decomposition route espoused by Liu et al. [15]. This is because the most effective slow release fertiliser of CDBM 2-UHP in the current study contained more urea (16.67\%) than the most effective fertiliser formulated by Liu et al. [15] whose urea content amounted to only $7.4 \%$, but the former cumulatively released only about $58.65 \%$ of the added $\mathrm{N}$ while the cumulative $\mathrm{N}$ released by the latter stood at $61.3 \%$ over the same 28 -day experimental period.

Its worthy noting that the biochar based slow release fertilisers employed in almost all the former studies have included clay minerals especially bentonite - with a purpose of improving the slow release capacities of those fertilisers as was confirmed by An et al. [19]. Shi et al. [31] for example included both bentonite and sepiolite in their biochar-based urea fertiliser formulation and reported that the biochar based urea fertiliser leached only about $60 \%$ of the added $\mathrm{N}$ against $85 \%$ leached from the pure urea over a 30-day experimental period. Puga et al. [13] also prepended bentonite to their formulated BFs, albeit it didn't play any role in slowing down $\mathrm{N}$ release from the formulated fertilisers. The study indicated that BFs with $\mathrm{BC} / \mathrm{N}$ ratios of between 5 and 10 solubilised an average of about $64 \%$ of the added $\mathrm{N}$ while those with $\mathrm{BC} / \mathrm{N}$ 
ratios ranging between 1 and 2 solubilised an average of $88 \%$ of $\mathrm{N}$ implying that it's only biochar to nitrogen ratios $(\mathrm{BC} / \mathrm{N})$ that influenced $\mathrm{N}$ release from the $\mathrm{BFs}$. The results obtained in the present study were inferior to those Puga et al. [13] attained because the BC/Urea (UHP) ratios of 5 adopted in the present study translate to $\mathrm{BC} / \mathrm{N}$ ratios of 13 but the average quantities of $\mathrm{N}$ solubilised from the urea and UHP containing BFs were about $87 \%$ and $64.4 \%$ of the added $\mathrm{N}$, respectively. However, CDBM 1-UHP and CDBM 2-UHP solubilised $62.94 \%$ and $58.56 \%$ of added $\mathrm{N}$, respectively which were less than the best average value of $64 \%$ obtained by Puga et al. [13].

In another relatedly similar study, Chen et al. [12] added kaolin to the biochar based urea hydrogen peroxide and found that $\mathrm{N}$ release from the formulated biochar-based UHP fertilisers decreased along increasing concentrations of kaolin in the fertilisers because high kaolin quantities resulted in a high density of the fertilizer granules produced leading to exceptional resistance to the migration of the nutrients from inside to the particle surface. However, although our study never included any clay in the formulation process of the BFs, the results obtained especially with UHP and biochar with large proportions of BM were satisfactory. The reduction in the amounts of $\mathrm{N}$ released along increasing concentrations of BM in the co-pyrolysed biochar used to formulate the BFs may be as a result of increase in surface area properties. As was observed in our recently concluded study (manuscript has just been accepted for publication) by Luyima et al. [32], large proportions of bone meal in the co-pyrolysed biomass led to production of porous biochar exemplified by the mat-like images obtained from the scanning electron microscopy (SEM). Both urea and UHP solutions might have been soaked up into those innumerable pores thus limiting their release into the solution.

The slow release nature of $\mathrm{P}$ observed in the co-pyrolysed biochars of the current study accorded well with the previous studies by Zhao et al. [16] and Lusta Filho et al. [5]. In a relatedly similar circumstance, Wang et al. [33] indicated that pyrolysing poultry litter slowed down $P$ release in comparison to un-pyrolysed poultry litter because charring transformed labile $\mathrm{P}$ in raw biomass to phosphate minerals in biochar that were not extractable in water even though they were proton-releasable $\left(\mathrm{H}^{+}\right)$in weak acids. The slow release of $P$ from the co-pyrolysed materials observed could have been due to the binding of the soluble phosphorus contained in both TSP and BM by alkali and other phosphate binding metals like $\mathrm{Ca}, \mathrm{Mg}$, $\mathrm{Fe}, \mathrm{Al}$, etc. which build up as materials pyrolyse. Indeed, Lusta Filho et al. [5] through an XRD analysis confirmed formations of different $\mathrm{P}$ forms that were insoluble in water even after 10 days of extraction of the biochar produced through co-pyrolysis of poultry litter with different phosphates.

\section{Agronomic efficiency of the BFs}

The better lettuce yields observed in BFs amendments than in pure mineral fertiliser amendments are in agreement with formerly concluded studies by Lusta Filho et al. [5], Chen et al. [12], Shi et al. [31], Liao et al. [34] and others. The improved agronomic efficiency observed with the application of BFs can be attributable to the slow release nature of the BFs because lessened rates of $\mathrm{N}$ release check on leaching and gaseous emissions of $\mathrm{N}$ while slow release of $\mathrm{P}$ prevents its fixation in the soil. The end result is that both $\mathrm{N}$ and $\mathrm{P}$ are released over an extended period of time along the entire life cycle of the plants and in quantities commensurate with the requirements of the growing plants which leaves no room for excesses in the soil. In their study, Liao et al. [34] found that the BFs improved nitrogen use efficiency and productivity of rape seed oil by increasing microbial activity which accelerated $\mathrm{N}$ cycling, concomitantly increasing $\mathrm{N}$ availability to crops. An early study by Li et al. [35] discovered that the potential of transformation of ammonium $\mathrm{N}$ to nitrate $\mathrm{N}$ as typified by the soil potential nitrification rates is affected by the abundance of the nitrifying micro-organisms in the soil. Subsequently Liao et al. [34] observed higher soil potential nitrification rates in the soils amended with the BFs than in those amended with urea indicating that BFs lead to the proliferation of nitrifying microbes which rapidly convert ammonium $\mathrm{N}$ to plant available nitrate $\mathrm{N}$ hence checking on gaseous loss of $\mathrm{N}$ resultantly improving $\mathrm{N}$ use efficiency.

The inferior performance of CDBM-Urea in comparison to the CDBM-UHP might have stemmed from the ability by the latter to sustain $\mathrm{N}$ supply over an extended period since Shen et al. [36] and Simonin et al. [37] indicated that the abundance of $\mathrm{N}$ oxidising microbes especially ammonia oxidising bacteria and nitrobacter (nitrite-oxidising bacteria) increases with $\mathrm{N}$ input. In fact, Liao et al. [34] reported elevated populations of ammonia oxidising bacteria in the soil amended with BFs as compared to other treatments. Besides N, Simonin et al. [37] reported that elevated $C$ input levels increased the abundance of both ammonia oxidising bacteria and nitrobacter whereas Liao et al. [34] observed an increase in the abundance of ammonia oxidising bacteria. In the current study, we observed increases in soil organic carbon in the BFs amended pots, an observation that accorded with that of Liao et al. [34] and which might help to explain the higher RNUE and yields in these treatments than in the pots that were amended with the conventional mineral fertilisers. 
Soil $\mathrm{pH}$ increased possibly owing to the residual basicity of most of the BFs used which might have created microsites in the soil where $\mathrm{P}$ adsorption was decreased as was explicated by Lusta Filho et al. [5]-which may also explain the improved RPUE observed. The roots produced with BFs amendments were denser and longer than those produced with pure P sources of TSP and BC possibly because the slow release of $\mathrm{P}$ led to its efficient utilisation by the growing plants. The dense and long roots thus facilitated improved access to nutrients by the growing lettuce which might have in turn contributed to the higher yields obtained with BFs than with the conventional fertilisers. The decreases in yield and RPUE observed in the second season can be attributable to the acidic nature of TSP which acidified the soil over time and hence, might have caused increases in P adsorbing metals such as iron, aluminium, etc. Confirming this notion is a study by Shen et al. [38] who observed a relatively strong negative linear relationship between decreases in soil $\mathrm{pH}$ and the above-ground yield of Lotus pedunculatus cv barsille. Another possible pathway through which BFs increased RPUE could have been through supporting the growth of arbuscular mycorrhizal fungi (AMF) as was adumbrated by Shen et al. [38]. Proliferation of AMF under biochar amended soils has been well documented by several previous studies and has been pointed out as one of the causes of the improved $P$ availability observed in those treatments. AMF is particularly important for plant acquisition of $\mathrm{P}$ because phosphate ions have low mobility in the soil and often elude capture by plant roots as was delineated by Smith and Read [39]. However, further studies to confirm these mechanisms with BFs are needed due to the dearth of data in that regard, even though that was not the objective of the current study.

\section{Conclusions}

The results of this study indicate that efficient $\mathrm{N}$ slowrelease fertilisers can be produced simply through capitalising on the biochar's great sorption power. Additionally, co-pyrolysis of animal manure biomass with BM improves the sorption capacity and boosts carbon retention of the resultant biochar along with supplanting the demand for the finite PR. Although CDBM $2 \mathrm{~N}$ fertilisers (CDBM 2-Urea and CDBM 2-UHP) were slightly more effective than CDBM $1 \mathrm{~N}$ fertilisers (CDBM 1-Urea and CDBM 1-UHP) in slowing-down $\mathrm{N}$ release, the CDBM $1 \mathrm{~N}$ fertilisers were agronomically more efficient than CDBM $2 \mathrm{~N}$ fertilisers and are thus recommended because they strike a good balance between $\mathrm{N}$ slow-release and agronomic efficiency. On the other hand, CDTP N fertilisers of CDTP-Urea and CDTP-UHP induced higher yields than any other amendment but their abysmally low nutrient use efficiencies render them an environmental risk and unprofitable to farmers. The bottom line, therefore, is that co-pyrolysis of animal biochar with BM (especially in $3: 1$, respectively) and subsequent soaking in UHP solution create sustainable slow-release $\mathrm{N}$ and $P$ fertilisers with elevated carbon retention capacities. However, the mechanisms underlying the observed attenuated rates of $\mathrm{N}$ release from the CDBM-Urea and CDBM-UHP fertilisers as well as their long term agronomic efficiency under field conditions require further explication in future studies.

\section{Acknowledgements \\ We would like to acknowledge the financial support received from the Coop- erative Research Program for Agricultural Science \& Technology Development of the Rural Development Administration that enabled us to defray experi- mental costs. We also want to acknowledge Chungnam national university for providing the equipments for the experiment including the green house.}

\section{Authors' contributions}

All authors contributed to the study conception and design. LD and JS collected data, conducted the laboratory and statistical analyses and wrote the manuscript, S-AW helped in data collection whenever we needed extra manpower while J-HL helped him with procuring the required materials and in some aspects of data collection and analysis. S-JP and T-KO supervised the experiment and offered technical guidance throughout the entire research period. All authors reviewed the written manuscript before submission to the journal for publication. All authors read and approved the final manuscript.

\section{Funding}

This research study was conducted with support from a research grant awarded by the Cooperative Research Program for Agricultural Science \& Technology Development of the Rural Development Administration of the Republic of Korea (Project No. PJ014253022020).

\section{Availability of data and materials}

The data sets supporting the conclusions made are included in the article while a limited amount of BFs fertilisers can be provided to whoever may want to experiment with them upon request.

\section{Competing interests}

All authors declare that they have no competing interests.

\section{Author details \\ ${ }^{1}$ Department of Bio-Environmental Chemistry, College of Agriculture and Life Sciences, Chungnam National University, Daejeon 34134, Korea. ${ }^{2}$ Department of Crop Science, College of Agriculture, Life and Environmental Sciences, Chungbuk National University, Cheongju 28644, Korea. ${ }^{3}$ Division of Soil and Fertilizer, National Institute of Agricultural Science, RDA, Wanju 55365, Korea.}

Received: 26 July 2020 Accepted: 28 August 2020

Published online: 09 September 2020

\section{References}

1. Calabi-Floody M, Medina J, Rumpel C, Condron LM, Hernandez M, Dumont M, de la Mora ML (2018) Smart fertilizers as a strategy for sustainable agriculture. Adv Agron. https://doi.org/10.1016/bs.agron.2017.10.003

2. Haygarth PM, Bardgett RD, Condron LM (2013) Nitrogen and phosphorus cycles and their management. In: Gregory PJ, Nortcliff S (eds) Soil conditions and plant growth. Willey-Blackwell, West Sussex, pp 132-159

3. Dawson CJ, Hilton J (2011) Fertiliser availability in a resource-limited world: Production and recycling of nitrogen and phosphorus. Food Policy 36:S14-S22. https://doi.org/10.1016/j.foodpol.2010.11.012 
4. Cordell D, Drangert JO, White S (2009) The story of phosphorus: Global food security and food for thought. Global Environ Change 19(2):292305. https://doi.org/10.1016/j.gloenvcha.2008.10.009

5. Lustosa Filho JF, Penido ES, Castro PP, Silva CA, Melo LCA (2017) Co-Pyrolysis of poultry litter and phosphate and magnesium generates alternative slow-release fertilizer suitable for tropical soils. ACS Sustain Chem Eng 5(10):9043-9052. https://doi.org/10.1021/acssuschemeng.7b01935

6. Szogi AA, Vanotti MB, Ro KS (2015) Methods for treatment of animal manures to reduce nutrient pollution prior to soil application. Curr Pollut Rep 1(1):47-56. https://doi.org/10.1007/s40726-015-0005-1

7. Kang J, Amoozegar A, Hesterberg D, Osmond DL (2011) Phosphorus leaching in a sandy soil as affected by organic and inorganic fertilizer sources. Geoderma 161(3-4):194-201. https://doi.org/10.1016/j.geode rma.2010.12.019

8. Kleinman PJA, Sharpley AN, McDowell RW, Flaten DN, Buda AR, Tao L, Bergstrom L, Zhu Q (2011) Managing agricultural phosphorus for water quality protection: principles for progress. Plant Soil 349(1-2):169-182. https://doi.org/10.1007/s11104-011-0832-9

9. Koneswaran G, Nierenberg D (2008) Beef Production: Koneswaran and Nierenberg Respond. Environ Health Perspect 116(9):A375. https://doi. org/10.1289/ehp.11716r

10. Brouček J, Čermák B (2015) Emission of Harmful Gases from Poultry Farms and Possibilities of Their Reduction. Ekologia. https://doi.org/10.1515/ eko-2015-0010

11. Moeletsi M, Tongwane M (2015) 2004 Methane and Nitrous oxide emissions from manure management in South Africa. Animals 5(2):193-205. https://doi.org/10.3390/ani5020193

12. Chen L, Chen Q, Rao P, Yan L, Shakib A, Shen G (2018) Formulating and optimizing a novel biochar-based fertilizer for simultaneous slow-release of nitrogen and immobilization of cadmium. Sustainability 10(8):2740

13. Puga AP, de Almeida Queiroz MC, Ligo MAV, Carvalho CS, Pires AMM, de Oliveira Santos Marcatto J, Andrade CA (2019) Nitrogen availability and ammonia volatilization in biochar-based fertilizers. Arch Agron Soil Sci. https://doi.org/10.1080/03650340.2019.1650916

14. Ye Z, Zhang L, Huang Q, Tan Z (2019) Development of a carbon-based slow release fertilizer treated by bio-oil coating and study on its feedback effect on farmland application. J Clean Prod. https://doi.org/10.1016/j. jclepro.2019.118085

15. Liu X, Liao J, Song H, Yang Y, Guan C, Zhang Z (2019) A biochar-based route for environmentally friendly controlled release of nitrogen: urea-loaded biochar and bentonite composite. Sci Rep. https://doi. org/10.1038/s41598-019-46065-3

16. Zhao L, Cao X, Zheng W, Scott JW, Sharma BK, Chen X (2016) Co-pyrolysis of biomass with phosphate fertilizers to improve biochar carbon retention, slow nutrient release, and stabilize heavy metals in soil. ACS Sustain Chem Eng 4(3):1630-1636. https://doi.org/10.1021/acssuschem eng.5b01570

17. Yao Y, Gao B, Chen J, Yang L (2013) Engineered biochar reclaiming phosphate from aqueous solutions: mechanisms and potential application as a slow-release fertilizer. Environ Sci Technol 47(15):8700-8708

18. Chen L, Chen XL, Zhou CH, Yang HM, Ji SF, Tong DS, Zhong ZK, Yu WH, Chu MQ (2017) Environmental-friendly montmorillonite-biochar composites: facile production and tunable adsorption-release of ammonium and phosphate. J Cleaner Prod 156:648-659

19. An X, Wu Z, Yu J, Cravotto G, Liu X, Li Q, Yu B (2020) Co-pyrolysis of biomass, bentonite and nutrients as a new strategy for the synthesis of improved biochar-based slow release fertilizers. ACS Sustain Chem Eng 8(8):3181-3190. https://doi.org/10.1021/acssuschemeng.9b06483

20. Murphy J, Riley JP (1962) A modified single solution method forthe determination of phosphate in natural waters. Anal Chim Acta 27:31-36

21. Okalebo JR, Gathua KW, Woomer PL (2002) Laboratory methods of soil and plant analysis: working manual, KARI, SSSEA, TSBF, SACRED Africa, second edition. Moi University, Nairobi

22. Sparks DL (2002) Environmental soil chemistry. Academic Press, Cambridge
23. Kalra YP (1998) Handbook of reference methods for plant analysis. CRC Press, Boca Raton

24. Wang HY, Zhou J (2014) Calculation of real fertilizer use efficiency and discussion on fertilization strategies. Acta Pedol Sin 51(2):216-225. https ://doi.org/10.11766/trxb201312110588

25. Cai Y, Qi H, Liu Y, He X (2016) Sorption/Desorption behavior and mechanism of $\mathrm{NH}_{4}{ }^{+}$by biochar as a nitrogen fertilizer sustained-release material. J Agri Food Chem 64(24):4958-4964. https://doi.org/10.1021/ acs.jafc.6b00109

26. Prost K, Borchard N, Siemens J, Kautz T, Séquaris JM, Möller A, Amelung W (2013) Biochar affected by composting with farmyard manure. J Environ Qual 42(1):164. https://doi.org/10.2134/jeq2012.0064

27. Kammann Cl, Schmidt HP, Messerschmidt N, Linsel S, Steffens D, Müller C, Koyrol HW, Conte P, Joseph S (2015) Plant growth improvement mediated by nitrate capture in co-composted biochar. Sci Rep. https://doi. org/10.1038/srep11080

28. Ventura M, Sorrenti G, Panzacchi P, George E, Tonon G (2013) Biochar reduces short-term nitrate leaching from a horizon in an apple orchard. J Environ Qual 42(1):76. https://doi.org/10.2134/jeq2012.0250

29. Haider G, Steffens D, Moser G, Müller C, Kammann Cl (2017) Biochar reduced nitrate leaching and improved soil moisture content without yield improvements in a four-year field study. Agr Ecosyst Environ 237:80-94

30. Haider G, Steffens D, Müller C, Kammann Cl (2016) Standard extraction methods may underestimate nitrate stocks captured by field aged biochar. J Environ Qual 45:1196-1204

31. Shi W, Ju Y, Bian R, Li L, Joseph S, Mitchell DRG, Munroe P, Taherymoosavi S, Pan G (2019) Biochar bound urea boosts plant growth and reduces nitrogen leaching. Sci Total Environ. https://doi.org/10.1016/j.scito tenv.2019.134424

32. Luyima D, Lee JH, Sung JK, Oh TK (2020) Co-pyrolysed animal manure and bone meal-based urea hydrogen peroxide (UHP) fertilisers are an effective technique of combating ammonia emissions. J Mater Cycles Waste Manage. https://doi.org/10.1007/s10163-020-01074-7

33. Wang Y, Lin Y, Chiu PC, Imhoff PT, Guo M (2015) Phosphorus release behaviors of poultry litter biochar as a soil amendment. Sci Total Environ 512-513:454-463. https://doi.org/10.1016/j.scitotenv.2015.01.093

34. Liao J, Liu X, Hu A, Song H, Chen X, Zhang Z. (2020) Effects of biocharbased controlled release nitrogen fertilizer on nitrogen-use efficiency of oilseed rape (Brassica napus L.). Sci Rep 10:11063. https://doi.org/10.1038/ s41598-020-67528-y

35. Li J, Nedwell DB, Beddow J, Dumbrell AJ, MCKew BA, Thorpe EL, Whitby C (2014) amoAGene abundances and nitrification potential rates suggest that benthic ammonia-oxidizing bacteria and not archaea dominate $\mathrm{N}$ cycling in the colne estuary. UK Appl Environ Microbiol 81 (1):159-165. https://doi.org/10.1128/aem.02654-14

36. Shen XY, Zhang LM, Shen JP, Li LH, Yuan CL, He JZ (2011) Nitrogen loading levels affect abundance and composition of soil ammonia oxidizing prokaryotes in semiarid temperate grassland. J Soils Sediments $11(7): 1243-1252$. https://doi.org/10.1007/s11368-011-0375-y

37. Simonin M, Le Roux X, Poly F, Lerondelle C, Hungate BA, Nunan $N$, Niboyet A (2015) Coupling between and among ammonia oxidizers and nitrite oxidizers in grassland mesocosms submitted to elevated $\mathrm{CO}_{2}$ and nitrogen supply. Microb Ecol 70(3):809-818. https://doi.org/10.1007/ s00248-015-0604-9

38. Shen Q, Hedley M, Camps Arbestain M, Kirschbaum MU (2016) Can biochar increase the bioavailability of phosphorus? J Soil Sci Plant Nutr. https ://doi.org/10.4067/s0718-95162016005000022

39. Smith SE, Read DJ (2010) Mycorrhizal symbiosis. Elsevier, Amsterdam

\section{Publisher's Note}

Springer Nature remains neutral with regard to jurisdictional claims in published maps and institutional affiliations. 